\title{
The Effect of Electronic Word of Mouth (E-Wom) and Brand Image on Repurchase Intention Moderated by Brand Trust in the Garuda Indonesia Airline
}

\author{
Nasya Nirma Sari ${ }^{1}$, Amrin Fauzi ${ }^{2}$, Endang Sulistya Rini ${ }^{2}$ \\ ${ }^{1,2}$ Master of Management Study Program on Postgraduate School of University of Sumatera Utara
}

Corresponding Author: Nasya Nirma Sari

\section{ABSTRACT}

Repurchase intention is a commitment of a customer formed as a consumer purchases a product or service. Many factors influencing repurchase intention, including the E-Word of Mouth (E_WOM), brand image and brand trust. E-WOM is an effective tool for building brand awareness, creating hype in the market, influencing purchasing decision and developing brand loyalty. Brand image is a description of association of consumer beliefs in a particular brand. Brand Trust is a customer's desire to rely on a brand at any cost. The present study is a survey using an associative quantitative approach aimed at determiniong the effect of EWOM and brand image on repurchase intention moderated by brand trust. The population of the study included all customers of Garuda Indonesia airline who have used the airline in the past year, especially the Garuda Indonesia Medan, which amounted to 36,000 during 2019. The sampling method used a sample formula with certain criteria so that were 100 samples. The data collection method used a questionnaire. Data analysis used path analysis. The results of the the study showm that E-WOM has a significant effect on Brand Trust. Brand Image has a significant influence on Brand Trust. Brand Trust has a significant positive effect on the Repurchase Intention variable. EWOM has a significant positive effect on variable Repurchase Intention. Brand Image has a significant effect on the Repurchase Intention variable through Brand Trust. E-WOM has a significant positive effect on variable Repurchase Intention through Brand Trust.
\end{abstract}

Brand Image has a significant effect on the Repurchase Intention. In other words, Brand Trust is proven to moderate the influence of Brand Trust on Repurchase Intention. It is recommended that Garuda Indonesia Airlines provide consistent, fast and quality service so that it gets positive reviews from customers which will increase Repurchase Intention of Garuda Indonesia flight tickets.

Keywords: E-WOM, Brand image, brand trust, repurchase intention.

\section{BACKGROUND}

The growth of air transportation in Indonesia has increased. In 2017, the number of air transport passengers was 109 million passengers while in 2016 it was 99.7 million passengers, an increase of $9.6 \%$ (www.inaca.or.id, 2019). The increase in the number of passengers led to the establishment of many airlines, but it also resulted in increasingly fierce competition between airlines. Airlines compete to provide affordable flight services. The types of flight services in Indonesia are divided into two, namely full service carriers and low cost carriers. One of the airlines with full service (full service carrier) is PT. Garuda Indonesia (Persero) Tbk. Garuda Indonesia was able to get various awards both nationally and internationally (Ruru, Sidik, and Goenawan, 2018). In addition, Garuda Indonesia also won the TOP Brand Award in Indonesia in 2020. 
Garuda Indonesia already has a good brand image in the minds of consumers so that it can become a top brand award at number one compared to its competitors. Although Garuda Indonesia is always ranked first in the Top Brand Awards, Garuda Indonesia has experienced a decline in its Brand Image in the Top Brand Index in 2017 to 2020 .

The decrease in TBI on Garuda Indonesia indicates a decrease in how the Garuda Indonesia brand is remembered (Mind Share) and a decrease in the desire to buy related in the future (Commitment Share). Commitment share is related to repurchase intention because it is related to the desire to buy in the future. A good brand image alone is not enough to generate profits for the company in the long run. Garuda Indonesia must be able to accommodate various consumer requests so that consumers will make repeat purchases in the future.

According to data published by databoks.katadata.co.id (2019) from Garuda Indonesia (Persero) Tbk, 2019, the total number of Garuda Indonesia passengers (domestic and international) in 2018, fell $1.46 \%$ to 23.61 million passengers, where previously in 2017 there were 24 million subscribers. According to the financial statements of PT. Garuda Indonesia Tbk, airline passengers for domestic and international flights decreased from 2017 to 2019. Likewise, Garuda Indonesia Medan Airlines experienced a decrease in the number of passengers both domestically and internationally from 36,000 passengers in 2020 to 9,000 passengers until October 2020. The main factor causing the decline in the number of passengers, especially in 2020 was the danger of the COVID-19 pandemic which caused concern high for each passenger. Garuda Indonesia must be able to accommodate various customer requests so that customers will re-purchase tickets in the future. When viewed from the number of customers who have decreased, this means that there are customers who are not interested in repeat purchases in the future. If customers do not repurchase, this can lead to a decrease in operating income.

Repurchase Intention is a consumer commitment that is formed after a consumer makes a purchase of a product or service where this commitment arises from the consumer's positive impression of a brand and satisfying consumption of the purchase (Hicks et al., in Arif, 2019). To increase repurchase interest, a positive E-WOM (Electronic Word of Mouth) is needed. According to Schau et al., in Arif (2019) that E-WOM has a significant effect on reducing the likelihood of being cheated from viewing the articles reviewed and this consumer satisfaction will be an online repurchase interest. E-WOM is based on informal communication between consumers who use various online media to discuss the positive or negative characteristics of any goods or services, or even producers or sellers (Litvin et al., in Nuseir, 2019).

According to data published by kompasiana.com (2019), Garuda Indonesia is in the public spotlight related to the case of a Garuda Indonesia customer who uploaded a photo of a handwritten menu list on a Garuda Indonesia business class flight. The customer was reported on suspicion of defamation. As a result of this report, Garuda Indonesia received negative public sentiment on various social media. The public considered that Garuda Indonesia's reaction was a form of anti-criticism and seemed excessive. This negative sentiment adds to the bad impression of Garuda Indonesia's E-WOM.

Garuda Indonesia has prepared a strategy during the COVID-19 pandemic to reduce negative sentiment from passengers, such as prioritizing flight safety and security and employees and services, holding intensive discussions with the government as the company's shareholder to obtain the necessary support, optimizing cargo services and actively supporting government efforts, especially those related to handling COVID-19 and implementing flight health protocols such as physical distancing in 
flights, implementing pre-medical checks for cabin crew, using protective equipment for crew on duty, disinfecting the fleet, eliminating reading material to minimize cross contamination and the use of monouse in the presentation of in-flight meals (www.cnbcindonesia.com, 2020).

According to previous research conducted by Panigoro et al., (2018) that EWOM has a positive and significant effect on Repurchase Intention, while according to research conducted by Savitri (2016) found that E-WOM has no effect on Repurchase Intention. These two studies have different results, causing a research gap between the two studies and this can support the phenomenon in this study.

\section{Electronic Word of Mouth (E - WOM)}

E-WOM is a traditional concept of WOM that was developed, E-WOM is a dynamic and continuous process of exchanging information between existing consumers, actual consumers or potential consumers about a product, service, brand or company that is open to many people and institutions via the internet (Ismagilova, et al., 2017). According to Thurau et al. in Haikal et al., (2018) Electronic Word of Mouth is a positive or negative statement made by consumers about a product or company that can be accessed by many people or institutions via the internet. Meanwhile, according to Cheung and Lee in Haikal et al.,(2018) stated that E-WOM is an online consumer review consisting of analysis and comments generated and posted by end-user products who have spent their money on the product and used it.

Based on this, the message contained in E-WOM is a very important message for consumers, because when it comes to information about product or service quality it will be an important reference in the decision-making process (Chevalier and Mayzlin in Imbayani and Gama, 2018). EWOM is generally considered beneficial because it is easily available and can be accessed by anyone who can use the internet (Evans and Erkan in Nuseir, 2019).

\section{Brand Image}

Tjiptono (2014:4) states that brand image is a description of the association of consumer beliefs towards certain brands. Meanwhile, Kotler \& Keller (2016) define brand image as "The perceptions and beliefs held by consumers, as reflected in the associations held in consumer memory." in the mind and memory of a consumer himself. This perception can be formed from information or past experiences of consumers with the brand. Kotler \& Keller (2016) suggest that "All companies strive to build a brand image with as many strong, favorable, and unique brand associations as possible." create a brand that is as unique as possible that can be profitable. Brand image is a number of beliefs, ideas and impressions held by a person about an object. Meanwhile, brand image is the perception and belief held by consumers, as reflected by associations embedded in consumers' memories.

Based on several definitions of brand image mentioned above, it can be concluded that brand image is what is perceived by consumers. Perception in this case is the process used by an individual to select, organize and interpret information inputs to create a meaningful picture of the world. In order for the brand image to be formed according to or close to the brand identity expected by the company, the company as a producer must be able to understand and exploit the elements that make up a brand that has a good image. This brand image is expected to produce an important quality according to consumer perception. This is called perceived quality (Perceived Quality).

\section{Brand Trust}

Brand Trust is defined as the consumer's belief and willingness to rely on the brand's ability to perform the promised function (Chudhuri and Holbrook, 2001). Brand trust is a customer's desire to rely on a brand with risks faced because expectations of the brand will lead to positive results (Lau and Lee, in Navarone 
and Evanita, 2019). According to Delgado et al., in Navarone and Evanita (2019) stated that Brand Trust (brand trust) is defined as a feeling of security held by consumers in their interactions with brands, that it is based on the perception that the brand is trusted and responsible for the interests and welfare of consumers. Brand trust comes from the consumer's experience with the brand. Brand trust is also obtained if the company is able to create and maintain positive emotional relationships with consumers, where the emotional connection must be built over a period of time that is not short but consistently and persistently (Delgado and Manuera, 2005).

\section{Repurchase Intention}

Repurchase Intention is part of consumer buying behavior where the match between the performance of the product or service offered by the company generates consumer interest to consume it again in the future (Wijaya in Apriyani and Suharti, 2017). Repurchase Intention is also a subjective probability that someone will buy a product or service continuously from an electronic supplier or store in the future (Yan and $\mathrm{Yu}$ in Arif, 2019). Meanwhile, according to Hellier in Juwiriyah (2019) that repurchase intention is to buy another product or service appointed from the same company by considering the previous situation with the current situation. Purchase intention (purchase intention) is a consumer commitment that forms after the consumer makes a purchase of a product or service. This commitment arises from consumers' positive impressions of a brand, and satisfying consumption of the purchase (Hicks et al., in Arif, 2019).

\section{Conceptual framework}

Brand Trust also has an influence on E-WOM, according to research by Cheung and Thadani, Sparks and Browning in Bhandary and Rogers (2017) that E-WOM can influence consumer perceptions and behavior online, including brand trust and their purchase intentions. According to previous research conducted by Haikal, Handayani and Nuryakin (2018), that EWOM has a positive effect on Brand Trust, E-WOM has various reviews about brands and this will affect consumer trust in brands. Reviews from internet users will shape brand perception. This will affect consumer confidence in the brand.

This study consists of 2 (two) independent variables namely Electronic Word of Mouth and Brand Image and 1 (one) moderate variable namely Brand Trust and 1 (one) dependent variable namely Repurchase Intention, so that the research concept framework can be described as follows:

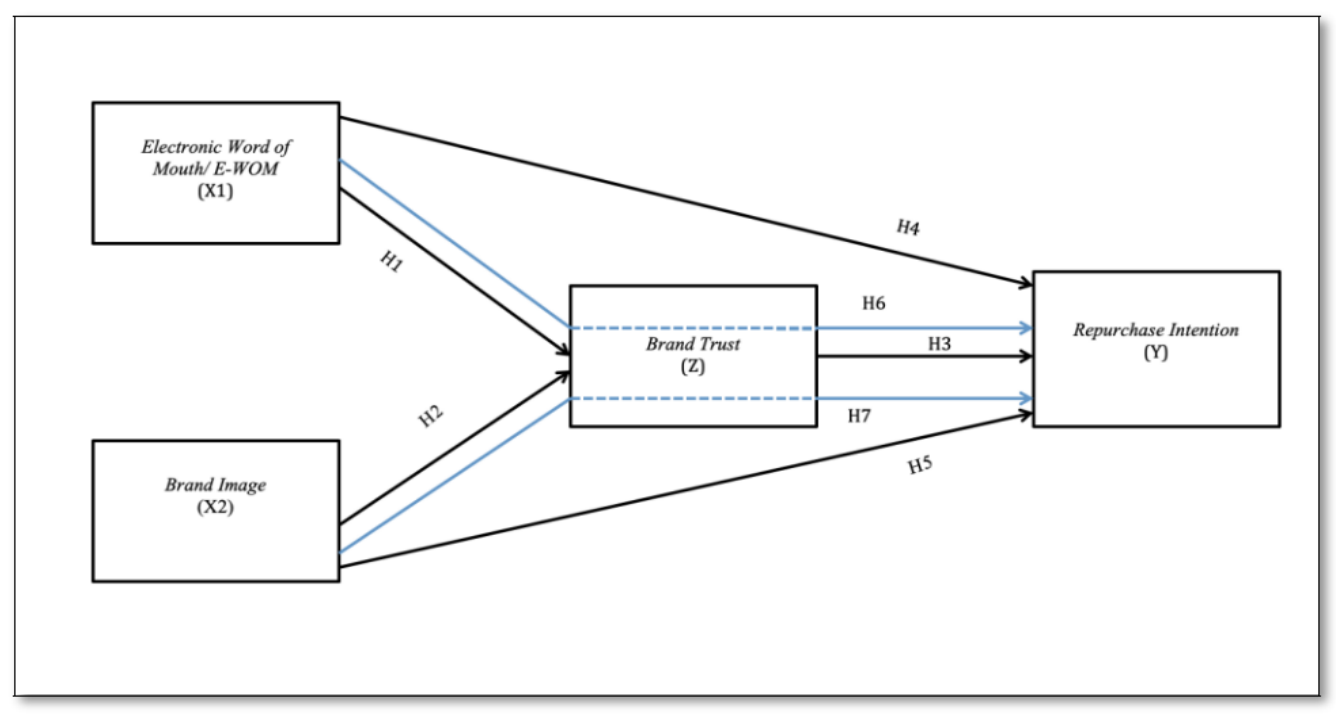

Figure 1. Conceptual Framework 


\section{Hypothesis}

1. Electronic Word of Mouth (E-WOM) has a positive and significant effect on Brand Trust on Garuda Indonesia airline.

2. Brand Image has a positive and significant effect on Brand Trust on Garuda Indonesia airline.

3. Brand Trust has a positive and significant effect on Repurchase Intention on the Garuda Indonesia airline.

4. Electronic Word of Mouth (E-WOM) has a positive and significant effect on Repurchase Intention on Garuda Indonesia airline.

5. Brand Image has a positive and significant effect on Repurchase Intention on Garuda Indonesia airline.

6. Electronic Word of Mouth has a positive and significant effect on Repurchase Intention through Brand Trust on Garuda Indonesia airline.

7. Brand Image has a positive and significant impact on Repurchase Intention through Brand Trust on Garuda Indonesia airlines

\section{RESEARCH METHODS}

This research is quantitative research with associative or relationship research design. According to Siregar (2013), associative research is research that aims to determine the relationship between two or more variables. The variables that are connected in this study include Electronic Word of Mouth and Brand Image as the independent variable (X), Brand Trust as the intervening variable (Z) and Repurchase Intention as the dependent variable (Y). The population of this research is all Garuda Indonesia airline customers who have used Garuda Indonesia airline in the last year, especially for Garuda Indonesia Medan airline, which amounted to 36,000 during 2019. The method of determining the sample in this study uses the purposive sampling method with the number of research samples is 100 people based on the calculation of the Slovin formula.

\section{RESULT AND DISCUSSION \\ Hypothesis Test Results \\ First Substructure Path Analysis \\ Hypothesis Test Results}

The analysis of the first substructure path includes the direct effect of E-WOM on Brand Trust, direct influence of Brand Image on Brand Trust, direct influence of Brand Trust on Repurchase Intention with the following results:

Table 1: First Substructure Path Analysis Results
\begin{tabular}{|l|l|l|l|l|}
\hline Variabel Bebas & \multicolumn{2}{|c|}{ Pengaruh } & \multirow{2}{*}{ Kesimpulan } \\
\cline { 2 - 4 } & t-hitung & Sig-p & R-square & \\
\hline E-WOM against Brand Trust & 8.300 & 0.000 & 0.413 & Significant \\
\hline Brand Image of Brand Trust & 8.367 & 0.000 & 0.417 & Significant \\
\hline Brand Trust on Repurchase Intention & 13.083 & 0.000 & 0.636 & Significant \\
\hline
\end{tabular}

\section{Effect of X1 (E-WOM) on Z (Brand Trust)}

Table 1 shows that the t-count value of $\mathrm{X} 1$ (E-WOM) is 8,300 with a significance value of $p=0.000$ and an $R$ square value $=0.413$. It can be seen that the $\mathrm{t}$-count (8.300) > t-table and p (0.000) $<0.05$. So it can be concluded that the variable $\mathrm{X} 1$ (E-WOM) has a significant positive effect on the variable $\mathrm{Z}$ (Brand Trust).

The results of the study show that EWOM has a significant influence on brand trust, this is evidenced by Garuda Indonesia airline where Garuda Indonesia was awarded as one of the best airlines in Asia in the category "Major Airlines" version of the TripAdvisor travel site based on world traveler reviews flight service users on the internet. This is due to customer trust in the Garuda Indonesia brand in the use of flight services (swa.co.id, 2020). The eWOM activity built by Garuda Indonesia created more positive statements than negative statements by actual or previous consumers regarding Garuda Indonesia's flight services 
via the internet. The existence of a positive E-WOM creates customer confidence in the Garuda Indonesia brand. This is in line with the opinion that Brand Trust is the willingness of consumers to believe in a brand even though it is risky because there is an expectation that the brand will give positive results.

\section{Effect of X2 (Brand Image) on Z (Brand Trust)}

Table 1 shows that the t-count value of X2 (Brand Image) is 8,367 with a significance value of $\mathrm{p}=0.000$ and an $\mathrm{R}$ square value $=0.417$. It can be seen that the t-count $(8.367)>$ t-table and p (0.000) < 0.05 . So it can be concluded that the variable X2 (Brand Image) has a significant positive effect on the variable $\mathrm{Z}$ (Brand Trust).

Based on the results of the study that brand image significantly affects brand trust, this is in line with the brand image created by Garuda Indonesia where Garuda Indonesia airline can maintain its brand image as one of the world's airlines with the best standards for implementing health and safety protocols during the pandemic version. Safe Travel Barometer. Garuda Indonesia brings a sense of security and comfort to passengers through the consistent implementation of health protocols and service standards that prioritize quality and safety. Garuda Indonesia also appeared before the public with a series of innovations in terms of branding. For example, the use of masks on the muzzle of aircraft in several fleets, and branding by cooperating with Raffi Ahmad as a celebrity. It is important for Garuda Indonesia to carry out the right branding by prioritizing the passenger experience (marketeers.com, 2020). This can also lead to consumer confidence in using Garuda Indonesia flight services because they feel safe and comfortable.

\section{Effect of $Z$ (Brand Trust) on $Y$ (Repurchase Intention)}

Table 1 shows that the t-count value of $\mathrm{Z}$ (Brand Trust) is 8,367 with a significance value of $p=0.000$ and an $R$ square value $=0.636$. It can be seen that the value of t-count (13.083) > t-table and $\mathrm{p}$ $(0.000)<0.05$. So it can be concluded that the variable $\mathrm{Z}$ (Brand Trust) has a significant positive effect on the variable $Y$ (Repurchase Intention).

The results of this study are in line with the brand trust created by the Garuda Indonesia airline where there is an increase in the number of passengers at the end of the year during the Covid-19 pandemic, which is 40,000 per day. Passengers believe that Garuda Indonesia has implemented health protocols and implemented physical distancing on the plane so that they feel safe and comfortable. This means that customer trust in the Garuda Indonesia airline brand creates repurchase intention even though Garuda Indonesia airline experienced a decline in passengers at the beginning of the Covid-19 pandemic and before (cnbcindonesia.com, 2020).

\section{Hypothesis Test Results of the Second Substructure Path Analysis}

The second substructure path analysis includes the direct effect of EWOM on Repurchase Intention, the direct effect of Brand Trust on Repurchase Intention, the indirect effect of E-WOM on Repurchase Intention and the indirect effect of Brand Image on Repurchase Intention with the following results:

Table 2. Second Substructure Path Analysis Results (Direct and Indirect Influence)

\begin{tabular}{|c|c|c|c|c|c|}
\hline \multirow{3}{*}{ Independent Variable } & \multicolumn{4}{|l|}{ Effect } & \multirow[t]{3}{*}{ Conclusion } \\
\hline & \multicolumn{2}{|c|}{ Direct } & \multicolumn{2}{|c|}{ Indirect } & \\
\hline & Sig-p & $\mathbf{R}$ square $_{\text {s }}$ & Sig-p & $\mathbf{R}$-square & \\
\hline E-WOM to Repurchase Intention & 0.000 & 0.512 & 0.000 & 0.706 & Significant \\
\hline Brand Image to Repurchase Intention & 0.000 & 0.541 & 0.000 & 0.719 & Significant \\
\hline
\end{tabular}


Direct and Indirect Effects of X1 (EWOM) on Y (Repurchase Intention)

Table 2 shows that directly the X1 variable (E-WOM) has a significant effect on the $\mathrm{Y}$ variable (Repurchase Intention) with a $\mathrm{p}$ value $=0.000$ and $\mathrm{R}$-square $=$ 0.512. While indirectly, the $\mathrm{X} 1$ variable (E_WOM) has a significant effect on the variable. Y (Repurchase Intention) through Brand Trust with a value of $p=0.000$ and $\mathrm{R}$-square $=0.706$. It can be seen that in the indirect effect, there is an increase in the Rsquare value to 0.706 . This means that in total variable $\mathrm{Z}$ (Brand Trust) is proven to moderate the effect of variable $\mathrm{X} 1$ (E_WOM) on variable Y (Repurchase Intention).

The results of this study are in line with what is happening in the field by the Garuda Indonesia airline where with a positive EWOM there is a growth in the number of passengers. This indicates that customers have increased trust in using Garuda Indonesia's air transportation services because it is safe and comfortable which is optimized through the consistent application of health protocols distributed through EWOM. The increase in the number of passengers at the end of the year during the pandemic continued with increasing customer repurchase interest. This shows that the effect of electronic word of mouth on repurchase intention has an indirect effect on the role of the mediating variable, namely brand trust.

\section{Direct and Indirect Effects of X2 (Brand Image) on Y (Repurchase Intention)}

Table 2 shows that the variable X2

(Brand Image) has a significant effect on the variable Y (Repurchase Intention) with a value of $p=0.000$ and $R$-square $=0.541$. While indirectly, the variable X2 (Brand Image) has a significant effect on the variable. Y (Repurchase Intention) through Brand Trust with a value of $p=0.000$ and $\mathrm{R}$-square $=0.719$. It can be seen that on the indirect effect, there is an increase in the Rsquare value to 0.719 . This means that in total variable $\mathrm{Z}$ (Brand Trust) is proven to moderate (strengthen) the effect of variable $\mathrm{X} 2$ (Brand Image) on variable $\mathrm{Y}$ (Repurchase Intention).

Brand Image has an effect on customer buying interest and is one of the key factors considered. The brand image formed by Garuda Indonesia to customers is that Garuda Indonesia consistently prioritizes service quality by presenting the best aspects such as changing aircraft interiors and adding AVOD (Audio and Video on Demand) facilities, on time and safe, fast and precise, clean and comfortable and reliable, professional, competent and ready to help customers. This further increases brand trust in customers so that customers will make repeat purchases in the future. Consumer buying behavior is often initiated and influenced by many external stimuli, both in the form of marketing stimuli and environmental stimuli. The personal characteristics of consumers that are used to process these stimuli are very complex, and one of them is the consumer's motivation to repurchase. Therefore, the formation of brand image greatly affects brand trust to repurchase.

\section{CONCLUSION}

1. E-WOM has a significant influence on Brand Trust.

2. Brand Image has a significant influence on Brand Trust.

3. Brand Trust has a significant positive effect on the $\mathrm{Y}$ variable (Repurchase Intention).

4. E-WOM has a significant positive effect on variable Y (Repurchase Intention).

5. Brand Image has a significant effect on variable Y (Repurchase Intention) through Brand Trust.

6. E-WOM has a significant positive effect on variable $\mathrm{Y}$ (Repurchase Intention) through Brand Trust.

7. Brand Image has a significant effect on variable Y (Repurchase Intention) through Brand Trust.

Acknowledgement: None 


\section{Conflict of Interest: None}

\section{Source of Funding: None}

\section{REFERENCES}

1. Ain, Nurul dan Ratnasari, Ririn Tri. (2015). Pengaruh Citra Merek Melalui Sikap Konsumen Terhadap Niat Beli Ulang Pada Produk Busana Muslim Zoya di Surabaya. Jurnal Ekonomi Syariah Teori dan Terapan. 2 (7): 553-569

2. Apriyani, N., \& Suharti. (2017). Analisis Pengaruh Persepsi Kebermanfaatan, Persepsi Kemudahan, dan Kepercayaan Terhadap Minat Beli Ulang Pengguna Smartphone Xiaomi. Jurnal Manajemen Dewantara, 1(1), 21-34.

3. Ardhanari, Margaretha. (2008). Customer Satisfaction Pengaruhnya Terhadap Brand Preference dan Repurchase Intention Private Brand. Jurnal Riset Ekonomi dan Bisnis. 8 (2): 58-69

4. Arif, Erfan Moh. (2019). The Influence of Electronic Word of Mouth (EWOM), Brand Image, And Price On Repurchase Intention of Airline Customers. Jurnal Aplikasi Manajemen. 17: 345-356.

5. Badan Pusat Statistik. (2019). Jumlah kunjungan wisman ke Indonesia Desember 2018 mencapai 1,41 juta kunjungan. www.bps.go.id. [online]. Tersedihttps://www.bps.go.id/pressrelease/2 019/02/01/1543/jumlah-kunjungan-wismanke-indonesia-desember-2018-mencapai-141-juta-kunjungan.html. [12 Maret 2020, 2:51 PM]

6. Bhandari, Manu and Rodgers, Shelly. (2017). What Does The Brand Say? Effects of Brand Feedback to Negative eWOM on Brand Trust and Purchase Intention. International Journal of Advertising. 1759$3948: 1-18$

7. Chaudhuri, A., \& Holbrook, M. (2001). Journal Maketing. The Chain of effectsfrom Brand Trust and brand effect to brand performance. 8193.

8. Cnbc Indonesia.com. (2020). Pandemi Bikin Kacau, Ini Strategi Garuda Demi Survive. [online]. Tersedia. https://www.cnbcindonesia.com/market/202 00824081002-17-181391/pandemi-bikinkacau-ini-strategi-garuda-demi-survive. [23 Desember 2020, 8:27 AM]
9. Cnbc Indonesia.com. (2020). Dampak Libur Panjang, Jumlah Penumpang Garuda Rekor!. [online]. Tersedia: https://www.cnbcindonesia.com/news/2020 1106152530-4-199875/dampak-liburpanjang-jumlah-penumpang-garuda-rekor. [15 Januari 2020, 4:05 PM]

10. Cynthiadewi, Putu Riri dan Hatammimi, Jurry. (2014). The Influence of Electronic Word of Mouth Toward Brand Image and Purchase Intention of 13 Shoes. International Conference on Economics, Education and Humanities. 66-70

11. Dewi, Janita Ika. (2005). Perspektif Baru dalam Strategi Branding, Bisnis dan Karir. Yogyakarta: Amara Books

12. Delgado, E., \& Manuera, J. (2005). Does Brand Trust Matter to Brand Equity? Journal Of Product \& Brand Managemant . 187-196.

13. Dharmayana, I Made Arya dan Rahanatha, Gede Bayu. (2017). Pengaruh Brand Equity, Brand Trust, Brand Preference, dan Kepuasan Konsumen Terhadap Niat Membeli Kembali. E-Jurnal Manajemen Unud. 6 (4): 2018-2046

14. Ferdinand, Augusty. (2006). Metode Penelitian Manajemen: Pedoman Penelitian untuk Skripsi, Tesis dan Disertai Ilmu Manajemen. Semarang: Universitas Dipenogoro

15. Foster, Bob dan Johansyah, Deni. (2019). EWOM'S Strength on Brand Image and Brand Trust and its' Impact on Interest to Buy Iphone Smartphone Products. International Journal of Innovation, Creativity and Change. 9 (12): 79-93

16. Garuda Indonesia.com. (2019). Annual Report 2019. www.garudaindonesia.com. [online]. Tersedia : https://www.garudaindonesia.com/id/en/investorrelations/annual-report-dan-sustainabilityreport/annual-report. [18 Juni 2020].

17. Ghozali, Imam. (2010). Analisis Multivariaet dengan Program SPSS. Semarang :Undip

18. Ghozali, Imam. (2013). Aplikasi Analisis Multivariete Dengan Program IBM SPSS 23, Edisi 8. Semarang : Penerbit Undip

19. Haikal, Reza, Handayani, Siti Dyah, dan Nuryakin. (2018). The Influence of Electronic Word of Mouth on Brand Image and Brand Trust and Its Impact on Purchase Intention (Empirical Study on Mi Fans Yogyakarta Community). International 
Nasya Nirma Sari et.al. The effect of electronic word of mouth (e-wom) and brand image on repurchase intention moderated by brand trust in the Garuda Indonesia airline.

Journal of Business Quantitative Economics and Applied Management Research. 5 (4): 22-29

20. Hamidun,Mohammad Alvin dan Sanawiri, Brillyanes. (2018). Pengaruh Electronic Word of Mouth Terhadap Purchase Intention Melalui Brand Image (Studi Pada Followers Instagram @ Ouvalresearch). Jurnal Administras i Bisnis. 61 (2): 61-68

21. Hasan, Ali dan Setiyaningtiyas, Niken Widiati. (2015). Pengaruh Electronic Word of Mouth Pada Media Sosial Facebook Terhadap Keputusan Berkunjung Ke Desa Wisata Nglanggeran Gunung Kidul. Jurnal media Wisata. 13 (1): 224-238

22. Hennig- Thurau, Thorsten, Gwinner P., Kevin, Walsh, Gianfranco, Gremler, Dwayne D. (2004). Electronic Word of Mouth Via Consumer Opinion Platforms : What Motivates Consumers To Articulate Themselves on The Internet. Journal of Interactive Marketing. 18 (1): 38 - 52

23. Hidayati,Mustikaningrum. (2018). Kepuasan Mahasiswa Dalam Memediasi Pengaruh Kualitas Layanan Jasa Pendidikan Terhadap Komunikasi Word Of Mouth (WOM). Jurnal Ilmiah UNTAG Semarang. 7 (2): $26-35$

24. Inaca.or.id. (2019). Maskapai Merugi di Tengah Arus Pertumbuhan Penumpang. www.inaca.or.id. [online]. Tersedia : https://inaca.or.id/maskapai-merugi-ditengah-arus-pertumbuhan-penumpang/. [9 Maret 2020, 2:10 PM)

25. Imbayani, I Gusti Ayu dan Gama, Agus Wahyudi Salasa. (2018). The Influence of Electronic Word of Mouth (E-Wom), Brand Image, Product Knowledge on Purchase Intention. Jurnal Ekonomi dan Bisnis Jagaditha. 5 (2): 145-153

26. Ismagilova, E., Dwivedi, Y. K., Slade, E., \& Williams, M. D. (2017). Electronic Word of Mouth (eWOM) in the Marketing Context: A State of the Art Analysis and Future Directions. Switzerland: Springer.

27. Ismasari, Rhisa Ayu dan Farida, Naili. (2016). Pengaruh Word of Mouth dan Brand Image Terhadap Repurchase Intention Melalui Brand Trust Smartphone Samsung Galaxy Series. Jurnal Ilmu Administrasi Bisnis. 5(4): 1-14

28. Juwariyah, Syaima. (2019). Pengaruh Brand Image, Brand Trust dan Perceived Price Terhadap Repurchase Intention Pada Tiket Maskapai Penerbangan Lion Air (Studi
Pada Mahasiswa/I Universitas Brawijaya Malang). Jurnal Ilmiah Mahasiswa FEB Universitas Brawijaya. 7 (2):1-11

29. Indrawati. (2015). Metode Penelitian Manajemen dan Bisnis. Bandung : PT Refika Aditama

30. Keller, K. L. (2013). Strategic Brand Management (Fourth ed.). English: Pearson Education Limited.

31. Kertajaya, Hermawan. 2013. Grow with Character: The Model Marketing. Jakarta: PT Gramedia Pustaka Utama.

32. Kompas.com.(2019). Berpergiandengan Pesawat Disebut Paling Aman. www.kompas.com. [online]. Tersedia: https://internasional.kompas.com/read/2019/ 03/11/20212381/bepergian -denganpesawat-disebut-paling-aman-inidatanya?page=all. [9 Maret 2020, 1:51 PM]

33. Kompas.com. (2019). Insiden Dua Pesawat Garuda Nyaris Tabrakan, Pilot Diduga Kerja Overtime. www.kompas.com. [online]. Tersedia: https://megapolitan.kompas.com/read/2019/ 12/13/18323431/insiden-dua-pesawatgaruda-nyaris-tabrakan-pilot-diduga-kerjaovertime?page $=$ all. $[18$ Maret 2020, 3:11 PM]

34. Kompas.com. (2020). Rekam Jejak Catatan Keuangan Garuda, BUMN yang Sering Merugi. [online]. Tersedia. https://money.kompas.com/read/2020/11/08 /080300426/rekam-jejak-catatan-keuangangaruda-bumn-yang-sering-merugi?page=all . [23 Desember 2020, 8:46 AM]

35. Kompasiana.com.

KelemahanManajemenKrisisGarudaIndones ia. www.kompasiana.com.[online],Tersedia https://www.google.co.id/amp/s/www.komp asiana.com/amp/alfredo0011/5d319cf90d82 $305 \mathrm{fba0e} 9 \mathrm{fc} 3 /$ kelemahan-manajemen-krisisgaruda-indonesia. [18 Maret 2020, 2:55 $\mathrm{PM}]$

36. Kotler Philip dan Kevin L. Keller. 2016. Marketing Management. Edisi ke 15. Penerbit Pearson Education Limited 2016.

37. Kotler, P. dan G. Amstrong. 2014. Dasar Dasar Pemasaran. Edisi ke-5. Intermedia, Jakarta.

38. Kusnandar, Viva Budy. (2019). Berapa Jumlah Penumpang Maskapai Garuda?. www.databoks.katadata.co.id. [online]. Tersedia

https://databoks.katadata.co.id/datapublish/2 
Nasya Nirma Sari et.al. The effect of electronic word of mouth (e-wom) and brand image on repurchase intention moderated by brand trust in the Garuda Indonesia airline.

019/06/20/berapa-jumlah-penumpang-

maskapai-garuda. [16 Maret 2020, 2:22 PM]

39. Kustini, Nuruni Ika. (2011). Experiential Marketing, Emotional Branding, and Brand Trust and Their Effect on Loyalty on Honda Motorcycle Product. Journal of Economics, Business and Accountancy Ventura. 14 (1): 19-28

40. Mabkhot, Hashed Ahmad, Shaari, Hasnizan, and Salleh, Salniza Md. (2017). The Influence of Brand Image and Brand Personality on Brand Loyalty, Mediating by Brand Trust: An Empirical Study. Jurnal Pengurusan. 50 (2017) : 71-82

41. Marketeers.com. (2020). Kreativitas CEO Garuda Indonesia Perkuat Brand Image. [online]. Tersedia: https://www.marketeers.com/kreativitasceo-garuda-indonesia-perkuat-brand-image/. [15 Januari 2021, 3.45 PM]

42. Marsono. (2019). Metode Penelitian Kuantitatif. Langkah - Langkah Menyusun Skripsi, Tesis atau Disertasi Menggunakan Teknik Analisis Jalur (Path Analysis). Bogor : Penerbit IN MEDIA

43. Matute, Jorge, Redondo-Polo, Yolanda and Utrillas, Ana. (2016). The Influence of EWOM Characteristics on Online Repurchase Intention. Online Information Review. 40 (7): 1090-1110

44. Navarone Nauffal dan Evanita, Susi. (2019). Pengaruh Service Quality dan Brand Trust Terhadap Repurchase Intention Melalui Customer Satisfaction sebagai Mediasi pada Produk Smartphone Samsung di Kalangan Mahasiswa Kota Padang. Jurnal Kajian Manajemen dan Wirausaha. 1(2) : 50-62

45. Nia, Itsna Ainin dan Mudiantono. (2016). Analisis Pengaruh Kepuasan dan Brand Trust Terhadap Minat Beli Ulang Pantene (Studi Pada 'Young Female' Semarang). Diponegoro Journal of Management. 5(3) $: 1-10$

46. Nuseir, Mohammed T. (2019). The Impact of Electronic Word of Mouth (e-WOM) on The Online Purchase Intention of Consumers in The Islamic Countries - A Case of (UAE). Journal of Islamic Marketing. 1759-0833 Panigoro, Aggi, Rahayu, Agus dan Gaffar, Vanesa. (2018). Analisis E-lifestyle dan E-Word Of Mouth terhadap Repurchase Intention Secara Online (Survei pada pelanggan produk fashion online Berrybenka di Fan Page
Instagram). Jurnal Ilmu Manajemen dan Bisnis. 9 (1): 25-33

47. Rangkuti, Freddy. (2013). Strategi Semut Melawan Gajah Untuk Membangun Brand Personal, Produk, dan Perusahaan. Jakarta : PT Gramedia Pustaka Utama

48. Ridwan.(2004).Statistik untuk Lembaga dan Instansi Pemerintah/ Swasta.Cetakan-1. Bandung : CV Alfabeta.

49. Ruru, Gabrielle Priscilla, Sidik, Amelia, dan Goenawan, Felicia. (2018). Analisis Isi Electronic Word of Mouth Pada Posting Instagram @garuda.indonesia. Jurnal EKomunikasi. 6 (2): 1-10

50. Sandjojo, Nidjo. (2011). Metode Analisis Jalur (Path Analysis) dan Aplikasinya. Jakarta : Pustaka Sinar Harapan

51. Sarwono, Jonathan. (2011). Mixed Methods, Cara Menggabung Riset Kuantitatif dan Riset Kualitatif Secara Benar. Jakarta : PT. Elex Media Komputindo

52. Siregar, Sofyan. (2013). Metode Penelitian Kuantitatif. Jakarta : Prenadamedia Group

53. Situmorang. (2010). Data Penelitian: Menggunakan Program SPSS. Medan: USU Press.

54. Sudjana. (2005). Metode Statistika. Bandung: Tarsito.

55. Sugiyono. (2012). Metode Penelitian Kombinasi (Mixed Methods). Edisi Kedua.Bandung : Alfabeta

56. Sujarweni, Wiratna V. (2015). Metodelogi Penelitian - Bisnis \& Ekonomi. Yogyakarta : Pustaka Baru Press

57. Swasty Wirania. (2016). Branding, Memahami dan Merancang Strategi Merek. Bandung: PT. Remaja Rosdakarya

58. Saidani, Basrah dan Arifin, Samsul. (2012). Pengaruh Kualitas Produk dan Kualitas Layanan Terhadap Kepuasan Konsumen dan Minat Beli Pada Ranch Market. Jurnal Manajemen Sains Indonesia (JRMSI). 3 (1): $1-22$

59. Sari, Ni Komang Lestya dan Santika, I Wayan. (2017). Pengaruh Brand Image, Brand Association, dan Brand Awareness Terhadap Repurchase Intention Produk Smartphone Merek Asus. E-Jurnal Manajemen. 6 (8): 4099-4126

60. Savitri, Eka Ayu. (2016). Pengaruh Promosi Melalui Media Sosial Terhadap Repurchase Intention Melalui Electronic Word of Mouth. Jurnal Ilmu Manajemen Universitas Tadaluko. 2 (3): 241-250 
61. Social Searcher. (2020). Analisis Sentimen Positif dan Negatif pada Garuda Indonesia di Internet. [online]. Tersedia : www.social-searcher.com. [16 Maret 2020, 4:55 PM]

62. Swa.co.id. (2020). Garuda Raih Penghargaan Maskapai Terbaik di Indonesia Versi TripAdvisor. [online]. Tersedia : https://swa.co.id/swa/trends/garuda-raihpenghargaan-maskapai-terbaik-diindonesia-versitripadvisor\#: :text=Garuda\%20Indonesia\% 20meraih\%20penghargaan $\% 20$ sebagai,secar a\%20berturut\%2Dturut\%20sejak\%202017. [15 Januari 2021, 3:03 PM]

63. Syahdany, Geny dan Trinanda, Okky. (2019). Pengaruh Electronic Word of Mouth dan Customer Experience terhadap Brand Trust Transmart Carrefour Kota Padang. Jurnal Kajian Manajemen dan Wirausaha. 1 (01): 226-231

64. Tjiptono Fandy dan Anastasia Diana. (2014). Total Quality Manajemen. Yogyakarta : Andi Offset

65. Tirto.id. (2020). Penumpang Turun Drastis, Garuda Rugi Rp. 10,34 T Semester I 2020. [online]. Tersedia: https://www.google.co.id/amp/s/amp.tirto.id /penumpang-turun-drastis-garuda-rugirp1034-t-semester-i-2020-fVpt. Desember 2020, 8:07 PM]

66. TopBrand Award. (2020). Top Brand Index Beserta Kategori. Topbrand-award.com. [online]. Tersedia: https://www.topbrandaward.com/top-brand-index/.[12 Maret 2020, 2:26 PM]
67. Torlak, Omer, Ozkara, Yalin Bechet, Tiltay, Muhammet Ali, Cengiz, Hakan and Dulger, Mehmet Fatih. (2014). The Effect of Electronic Word of Mouth on Brand Image and Purchase Intention: An Application Concerning Cell Phone Brands for Youth Consumers in Turkey. Journal of Marketing Development and Competitiveness. 8 (2): 61-68

68. Turgut, Merve U. and Gultekin, Beyza. (2015). The Critical Role Of Brand Love in Clothing Brands. Journal of Business, Economics \& Finance. 4(1): 126-152.

69. Wiryono, Singgih. (2019). Penumpang Garuda Indonesia Turun Hingga 20,6 Persen. [online]. Tersedia : https://megapolitan.kompas.com/read/2019/ 12/27/19552781/penumpan g-garudaindonesia-turun-hingga-206-persen. [16 Maret 2020, 2:32 PM]

70. Zuhriyah,Aminatuz Dewi. (2019). Tren Kenaikan Wisatawan Domestik Didominasi Generasi Milenial. www.ekonomi.bisnis.com. [online]. Tersedia https://ekonomi.bisnis.com/read/20190910/1 2/1146575/tren-kenaikan-wisatawandomestik-didominasi-generasi-milenial. [12 Maret 2020, 2:45 PM]

How to cite this article: Sari NN, Fauzi A, Rini ES. The effect of electronic word of mouth (ewom) and brand image on repurchase intention moderated by brand trust in the Garuda Indonesia airline. International Journal of Research and Review. 2021; 8(9): 81-91. DOI: https://doi.org/10.52403/ijrr.20210912 